\title{
Grzegorz ĆWIĘKAŁA
}

Państwowa Wyższa Szkoła Zawodowa im. rtm. Witolda Pileckiego w Oświęcimiu gcwiekala@o2.pl

\section{KORZENIE MYŚLI POLITYCZNEJ ŚRODOWISKA SKUPIONEGO WOKÓŁ TYGODNIKA „NAJWYŻSZY CZAS!”}

\section{ABSTRACT The Najwyższy Czas! weekly - the roots of the political thought}

Conservatism and liberalism as ideologies are in conflict but only seemingly. Synthesis is possible. The proof is given by the journalists of the Najwyższy Czas! weekly. In short: liberalism in economy and conservatism in a social life and in morality. The roots of their conceptions we can find in a number of past and contemporary thoughts of the philosophers, economists, sociologists and politicians. Adam Smith gave the basis for economic opinions, above all about the "invisible hand" in the free market. Edmund Burke was the first conservative, who noticed the essence of liberal values. The propagator of laissez-faire concept - Frederic Bastiat declared oneself in favour of stable law and the minimal statism (night-watch state), which will guarantee individual's freedom. Representatives of Austrian School - Ludwig von Mises and Friedrich August von Hayek specified and extended French thinker's conceptions, became a natural inspirers of Polish liberal conservatives. The practical ways of applying a liberal economy with preserving conservatives values gave Margaret Thatcher and Ronald Reagan.

Keywords: conservative liberalism, Najwyższy Czas! weekly magazine, political thought

Słowa kluczowe: konserwatywny liberalizm, „Najwyższy Czas!”, myśl polityczna 
G łównym celem niniejszego artykułu jest prezentacja pozornie trudnych do połączenia poglądów liberalnych z konserwatywnymi, które prezentowane są w całej swej okazałości w tygodniku „Najwyższy Czas!”. To karkołomne logicznie przedsięwzięcie nie znalazło jak do tej pory w polskiej nauce całościowego opracowania. Zajmowano się osobno liberalizmem ${ }^{1} \mathrm{i}$ konserwatyzmem ${ }^{2}$, wśród których wymieniano nurt liberalno-konserwatywny bądź konserwatywno-liberalny, ale brak jest analizy środowiska prezentującego $\mathrm{z}$ wielkim przekonaniem poglądy łączące te dwie wielkie doktryny. Zdaniem autora jest to luka, którą należy wypełnić, ponieważ środowisko owo na to zasługuje, ze względu choćby na, rzadko spotykaną w Polsce, konsekwencję głoszenia swoich, wcale nie prostych i łatwych, poglądów.

Wypada na początku zwrócić uwagę, że niniejsze opracowanie skupia się na okresie 1990-2010, a więc pierwszych 20 latach funkcjonowania tygodnika na rynku wydawniczym. Autor przyjął taką cezurę ze względu na przekonanie o pełnym wykształceniu się myśli tego środowiska w tym czasie. Jest to również związane z wieloma opracowaniami poświęconymi II Rzeczypospolitej, a dotyczącymi ówczesnej prasy w podobnym zakresie czasowym (autor zdaje sobie jednocześnie sprawę z przyczyn takiego, a nie innego czasu trwania II RP). Jest wreszcie powód związany z samym pismem. Otóż w 2007 roku doszło do zmian właścicielskich i zmiany wydawcy „Najwyższego Czasu!”. Jest to moment, od którego nastąpiły ewolucyjne przemiany w zespole redakcyjnym. Choć linia ideowa została utrzymana, to jednak usunięcie się założyciela pisma Janusza Korwin-Mikkego z wpływu na drukowane treści zakończyło pewną epokę funkcjonowania tygodnika. Stąd też główny nacisk źródłowy położony jest na wzmiankowany okres, ze szczególnym uwzględnieniem lat 90. XX wieku, kiedy to kształtowała się wyrazistość poglądów środowiska. Późniejsze teksty w dużej mierze jedynie uzupełniają początkowe dyskusje, poszukując inspiracji w jeszcze innych zakątkach myśli politycznej. Jedynym znaczącym novum jest zwiększające się zainteresowanie libertarianizmem, co nastąpiło dzięki otwartemu dostępowi do tekstów autorów anglosaskich, a co ma również odbicie w dalszej części niniejszego artykułu.

Konfrontacja liberalizmu i konserwatyzmu trwa od początku powstania obydwu doktryn, mało tego, źródeł myśli konserwatywnej poszukuje się w powstaniu

Wśród najważniejszych autorów można wymienić: J. Szacki, Liberalizm po komunizmie, KrakówWarszawa 1994, Demokracja; W. Kwaśnicki, Historia myśli liberalnej. Wolność, wtasność, odpowiedzialność, Warszawa 2000; Z. Rau, Liberalizm. Zarys myśli politycznej XIX i XX wieku, Warszawa 2000, Biblioteka Aletheia, 10; J. Bartyzel, W gaszczu liberalizmów. Próba periodyzacji i klasyfikacji, Lublin 2004, Biblioteka Cywilizacji.

2 Wśród najważniejszych autorów można wymienić: W. Mich, Myśl polityczna polskiego ruchu konserwatywnego, Lublin 1994, Wyktady Otwarte UMCS, 10; R. Skarzyński, Konserwatyzm - zarys dziejów filozofii politycznej, Warszawa 1998; G. Sordyl, Spadkobiercy Stańczyków. Doktryna konserwatyzmu polskiego w latach 1979-1989, Kraków 1999, Ararat; B. Szlachta, Z dziejów polskiego konserwatyzmu, Kraków 2000, Ararat; K. Wandowicz, Wspótczesny konserwatyzm polityczny w Polsce (1989-1998), Wrocław 2000, Acta Universitatis Wratislaviensis. Politologia, 30; J. Bartyzel, Konserwatyzm bez kompromisu. Studium z dziejów zachowawczej myśli politycznej w Polsce w XX wieku, Toruń 2001. 
liberalnych koncepcji Johna Locke’a ${ }^{3}$. Oczywiście rzadko kiedy da się zdefiniować danego myśliciela czy filozofa jako „czystego” liberała bądź konserwatystę. Przeważnie mówi się o rozmaitych nurtach jednej i drugiej doktryny. Andrew Heywood wśród różnych konserwatyzmów wyróżnia: konserwatyzm autorytarny, konserwatyzm paternalistyczny, w ramach którego rozróżnia dwie tradycje: konserwatyzmu jednego narodu i chrześcijańską demokrację, oraz konserwatyzm libertariańskił. Z kolei Ryszard Skarzyński wymienia osiem typów konserwatyzmu: organiczny, metafizyczny, społeczno-kulturowy, decyzjonistyczny (ten wywodzi się z konserwatyzmu metafizycznego i ultramontanizmu), status quo, ewolucjonistyczny, reformistyczny i radykalny'. Badacz i znawca myśli politycznej konserwatyzmu, Bogdan Szlachta, powołując się na Samuela P. Huntingtona i jego terminologiczne ustalenia, podaje, że można wyróżnić konserwatyzm arystokratyczny, konserwatyzm sytuacyjny i konserwatyzm jako postawę ${ }^{6}$. Dodatkowym utrudnieniem jest rozróżnianie tzw. konserwatyzmów narodowych, charakterystycznych dla danego narodu lub państwa i opierających się na innych zasadach dominujących, np. konserwatyzm brytyjski traktujący zachowawczość raczej jako formę przygotowania się do ewolucyjnej zmiany czy konserwatyzm krajów latynoskich zawierający dużą dawkę autorytaryzmu i populizmu? ${ }^{7}$ Podobnie rzecz ma się z liberalizmami. Heywood wymienia: liberalizm klasyczny, gospodarczy, społeczny i neoliberalizm$^{8}$. Z kolei Jacek Bartyzel wyróżnia szerszą gamę odmian liberalizmu: liberalizm filozoficzny, religijny, moralno-obyczajowy, polityczny i ekonomiczny ${ }^{9}$. Jak widać z powyższego zestawienia, które jest tylko zarysem sytuacji, oba nurty myślowe wytworzyły nieskończoną wręcz liczbę odmian i rodzajów.

$\mathrm{Na}$ czym więc polega ów konflikt? Jest przynajmniej kilka jego obszarów. Po pierwsze, liberalizm i konserwatyzm wyrosły z dwóch różnych pni społecznych - podstawową i zasadniczą różnicą była chęć zmieniania świata przez liberałów i zdecydowany sprzeciw wobec tego konserwatystów. Liberalizm powstał jako odpowiedź na rozpadający się system feudalny, myśliciele liberalni przyznali jednostce prawa wynikające z prawa natury, wolność, a nowe (przekształcone) społeczeństwo miało powstać w oparciu o umowę społeczną. Konserwatywne idee są dosyć stare, ale nie muszą być ujawniane, gdyż wydają się naturalne dla społeczeństwa feudalnego. Właśnie wraz z upadkiem tego systemu konserwatyści zaczęli bronić arystokratycznego, skostniałego podziału społecznego nieprzyznającego jednostce wielu praw. Po drugie, jest to stosunek do indywidualizmu. Liberalizm uznaje indywidualizm każdego rozumu za podstawę działania

B. Szlachta, Konserwatyzm. Z dziejów tradycji myślenia o polityce, Kraków-Warszawa 1998, s. 9.

A. Heywood, Ideologie polityczne. Wprowadzenie, przeł. M. Habura, N. Orłowska, D. Stasiak, red. nauk. T. Żyro, Warszawa 2007, s. 97-104.

R. Skarzyński, Konserwatyzm - zarys dziejów..., s. 18-31.

6 S.P. Huntington, Conservatism as an Ideology, „The American Political Science Review” 1957, Vol. 51, nr 2, s. 454-460, podaję za: B. Szlachta, Konserwatyzm. Z dziejów tradycji..., s. 243, przyp. 10.

A. Heywood, Ideologie polityczne..., s. 84 .

8 Tamże, s. 60-74.

9 J. Bartyzel, W gaszczu liberalizmów..., s. 29-130. 
jednostek, a społeczeństwo ma być zbiorem wolnych indywidualności. Konserwatyści nie uznawali ani indywidualizmu, ani racjonalizmu, uznając, iż porządek stworzony przez Stwórcę jest najlepszym, co mogło spotkać ludzkość, i należy go bronić za wszelką cenę. Trzecim obszarem jest kwestia równości. Liberałowie uznają równość każdej jednostki cieszącej się identycznymi prawami, szczególnie prawem do własności, które ma prowadzić do dobrobytu i szczęśliwości. Dla konserwatystów nierówności systemu arystokratycznego są czymś naturalnym, stworzonym przez Boga, a co za tym idzie prawa ludzi zależą od Boga, który wyznacza ich pozycję społeczną. Po czwarte, liberałów i konserwatystów różni podejście do stosunków państwo-jednostka. Ci pierwsi odrzucają najczęściej jakąkolwiek interwencję państwa w prywatność człowieka, traktując państwo jako gwaranta prawa do własności, a jego siłę traktując w kategorii bogactwa. Konserwatyści natomiast widzieli w państwie gwaranta utrzymania stabilności i niezmienności stosunków społecznych, stąd nie wzbraniali się przed interwencją państwa w życie jednostki. Jako piąty obszar należy wymienić system rządów. O ile dla liberałów oczywistym i naturalnym systemem jest demokracja, o tyle konserwatyści mieli co do niej wiele wątpliwości, preferując raczej silną władzę jednostki, najlepiej niepochodzącej z wyborów, a z woli Boga ${ }^{10}$.

Należy zauważyć, że powyższe rozważania są charakterystyczne dla sporów XIX-wiecznych, natomiast im bliżej czasów współczesnych, tym po częstokroć stanowiska obu nurtów zbliżały się do siebie w wielu kwestiach. Można to tłumaczyć pojawieniem się wspólnego wroga w postaci socjalizmu. Samo połączenie liberalizmu z konserwatyzmem nie jest wytworem naszych czasów. Już wielu myślicieli w XIX wieku można by zakwalifikować do nurtu konserwatywno-liberalnego, mimo iż wielokrotnie są zaliczani w poczet „czystych” liberałów bądź „czystych” konserwatystów. Uwagi te dotyczą takich myślicieli, jak Benjamin Constant, Alexis de Tocqueville, Lord Acton, John Stuart Mill czy Frédéric Bastiat ${ }^{11}$. Poza tym wskazuje się, że w zakresie spraw gospodarczych nie sposób odróżnić konserwatyzmu od liberalizmu klasycznego. Natomiast sam liberalizm nie może funkcjonować bez moralności (jakże charakterystycznej dla konserwatyzmu), jeśli nadal ma być ostoją dla podstawowych dla siebie wartości - wolności, indywidualizmu, postępu ${ }^{12}$. Harmonijne połączenie tych dwóch nurtów myślowych jest więc możliwe. O liberalnym konserwatyzmie lub konserwatywnym liberalizmie pisze wielu badaczy, żeby wymienić tylko wspomnianych już Andrew Heywooda, Jacka Bartyzela czy Jana Kłosa. Najbardziej jednak wymownymi przykładami tego mariażu są koncepcje Nowej Prawicy, dające podstawy dwóm najdonioślejszym ich realizacjom - thatcheryzmowi i reaganomice, które zostaną omówione w dalszej części niniejszego artykułu.

W Polsce środowiskiem, które podjęło trud głoszenia poglądów konserwatywno-liberalnych, są autorzy skupieni wokół tygodnika „Najwyższy Czas!”. Czasopismo to

10 R. Skarzyński, Od liberalizmu do totalitaryzmu. Z dziejów myśli politycznej XX w., t. 1, Warszawa 1998, s. 65, Studia i Materiaty Wyższej Szkoty Dziennikarstwa im. Melchiora Wańkowicza w Warszawie, 1.

11 Do takich wniosków doszedł w swej pracy Jan Kłos, zaliczając te postaci w poczet konserwatywnego liberalizmu. Zob. J. Kłos, Wolność, indywidualizm, postęp. Liberalizm konserwatywny wobec nowoczesności, Lublin 2007, s. 16.

12 Tami̇e, s. 28. 
należy zaliczyć raczej do niszowych, choć posiadających stabilną pozycję i długą, jak na warunki III Rzeczypospolitej, ponad dwudziestoletnią tradycję. Tygodnik jest w pewnej mierze prasowym ramieniem politycznych projektów swojego założyciela, wydawcy i długoletniego redaktora naczelnego Janusza Korwin-Mikkego. Jakkolwiek treści związane z polityczną działalnością lidera dominują w okresach wyborczych, to poza nimi czasopismo pretenduje do pozycji tygodnika opinii publicznej, wszak z silnie zarysowaną linią ideologiczną.

Problemem podstawowym zatem dla środowiska skupionego wokół „Najwyższego Czasu!” jest pytanie, w jaki sposób łączyć te dwie idee, aby zaszczepić je na grunt polski, by móc wdrażać je w życie? Najkrótszą odpowiedzią będzie stwierdzenie: liberalizm w gospodarce, konserwatyzm w życiu społecznym. Jak pisze Artur Górski: Zazębienie ideowo-programowe jest wyraźne. Konserwatyści wiedza, że bez haset wolnorynkowych, tak dziś istotnych dla zmian gospodarczych w naszym kraju, nie uzyskaja poparcia spotecznego i pozostana formacja „kanapowa”. Liberatowie zaś maja świadomość, że konserwatyści doskonale uzupetniaja ich postulaty gospodarcze i gwarantuja prawicowy charakter liberalizmu. W zwiazku z tym gotowi sq nawet akceptować monarchistyczne "fanaberie" co niektórych konserwatystów ${ }^{13}$.

Tam, gdzie tę maksymę trudno jest zastosować ze względu na fundamentalne różnice, jedna ze stron musi ustąpić. W tym miejscu można podać przykład systemu rządów. Otóż zasady liberalne skłaniałyby omawiane środowisko ku demokracji, jednakże pierwiastek konserwatywny każe dodawać tutaj obawę. Dzięki temu powstaje konstrukcja, w której dopuszcza się istnienie rządów autorytarnych (być może w formie monarchii), których podstawowym zadaniem ma być wprowadzenie liberalnych zasad gospodarczych. W ten sposób zaspokojone mają zostać oba pierwiastki. Ten konserwatywny zyskuje silne i bogate państwo oparte na stabilnej władzy, a ten liberalny otrzymuje wolność jednostki przy państwie minimalnym koncentrującym się na zabezpieczeniu tejże wolności - zarówno w wymiarze wewnętrznym (rozumiane przez pryzmat bezwzględnej praworządności), jak i zewnętrznym (siła i bogactwo mają zapewnić silną i sprawną armię) ${ }^{14}$.

Problemem może jednak być brak podłoża społecznego i wyborczego dla tak definiowanych poglądów. Tam, gdzie liberalny konserwatyzm odniósł sukces wyborczy (przede wszystkim Stany Zjednoczone i Wielka Brytania), funkcjonuje silna i stabilna klasa średnia będąca naturalnym elektoratem wyborczym. W Polsce, szczególnie tuż po zmianach 1989 roku, klasy średniej brakowało albo była ona w stanie szczątkowym. Takie ostrzeżenia i przestrogi również pojawiały się na łamach tygodnika ${ }^{15}$, ale były i głosy odwołujące się raczej do indywidualnych cech wyborców, bez względu na ich przynależność zawodową, płciową czy jakąkolwiek inną. Wyborcą konserwatywnych liberałów miałby być przede wszystkim człowiek twórczy, wierzący w zasady, w siłę prawa, w wolność osobistą ${ }^{16}$.

13 A. Górski, Trzeba te pojęcia taczyć, „Najwyższy Czas!” 1992, nr 28, s. 3.

14 Tamże.

15 J. Burliński, Flota bez morza, „Najwyższy Czas!” 1992, nr 4, s. 10.

16 Kto z nami, kto przeciwko nam, „Najwyższy Czas!” 1990, nr 7, s. 1, 3. 
Należy wreszcie zauważyć, że pierwiastek liberalny, którym określa się samo środowisko na stronach tytułowych „Najwyższego Czasu!" ${ }^{7}$, niektórzy badacze zamieniają na pierwiastek libertariański. Czyni tak np. Jacek Bartyzel ${ }^{18}$, z kolei Łukasz Machaj, pisząc o „środowisku UPR i »Najwyższego Czasu! «”, określa ten nurt jako konserwatywno-liberalny z elementami monarchizmu i libertarianizmu ${ }^{19}$. Ta libertariańska domieszka wskazuje na silnie zradykalizowany liberalizm środowiska, szczególnie wtedy, gdy mowa jest o zasięgu działania państwa czy gospodarce. Jednakże zważywszy na wielonurtowość samego libertarianizmu i silny w nim wpływ koncepcji anarchoindywidualistycznych ${ }^{20}$, lepsze w definiowaniu ideowym środowiska jest raczej określenie Machaja.

Wydaje się, że mówiąc o inspiracjach jakiegoś środowiska, trzeba najpierw odnaleźć klucz do koncepcji ideologicznych głoszonych przez to środowisko. Dla publicystów związanych z „Najwyższym Czasem!” takim kluczem będzie styk konserwatyzmu i liberalizmu. Inspiracji należy więc poszukiwać w tych dwóch wielkich filozofiach politycznych, ale tylko tam, gdzie ten styk nie wywołuje konfliktu, gdzie da się go pogodzić, co zostało już zarysowane wcześniej. Lider środowiska Janusz Korwin-Mikke sam siebie określa mianem konserwatysty. W jednej z relacji dla swego biografa Cezarego Zawalskiego stwierdził nawet: od tej pory jestem absolutnie czarna reakcja ${ }^{21}$. Bogdan Szlachta zauważa, że środowisko tworzone przez Korwin-Mikkego i Stanisława Michalkiewicza swoich inspiracji poszukuje raczej w brytyjskim i amerykańskim konserwatyzmie reprezentowanym w wersji teoretycznej przez Miltona Friedmana i Friedricha Augusta von Hayeka, a w wersji praktycznej przez Ronalda Reagana i Margaret Thatcher ${ }^{22}$. W Polsce postaci te kojarzą się bardziej z ich poglądami czy reformami gospodarczymi aniżeli odwołaniami do koncepcji zachowawczych, ale to jeszcze raz pokazuje, że styk konserwatyzmu, szczególnie tego anglosaskiego, z liberalizmem jest możliwy. Te odwołania do obcych wzorów spowodowane są słabością polskich konserwatystów i liberałów, chociaż warto w tym miejscu zauważyć, że tacy międzywojenni antyetatyści, tworzący krakowską szkołę ekonomiczną, jak Adam Krzyżanowski²3, Adam Heyde ${ }^{24}$ czy Ferdynand Zweig's, odcisnęli pewne piętno na poglądach omawianego środowiska.

17 Podtytuł brzmi: „Pismo konserwatywno-liberalne”.

18 J. Bartyzel, W gąszczu liberalizmów..., s. 181 i 186. Należy tu jednak poczynić uwagę, że określenie to dotyczy politycznego wymiaru działalności lidera środowiska Janusza Korwin-Mikkego i Ruchu Polityki Realnej (później Unii Polityki Realnej), a nie całości środowiska skupionego wokół tygodnika.

19 Ł. Machaj, Za i przeciw Europie. Integracja europejska w polskiej myśli politycznej w latach 1989-2001, Wrocław 2006, s. 12, Acta Universitatis Wratislaviensis, 2952.

20 Zob. szerzej: M. Modrzejewska, Libertariańskie koncepcje jednostki i państwa we wspótczesnej amerykańskiej myśli politycznej, Kraków 2010, Prace Amerykanistyczne UJ.

21 C. Zawalski, Prezes. Janusz Korwin-Mikke - publicysta i polityk, Warszawa 2004, s. 18.

22 B. Szlachta, $Z$ dziejów..., s. 219.

23 W. Bernacki, Krzyżanowski Adam, [w:] Stownik historii doktryn politycznych, t. 3, red. M. Jaskólski, Warszawa 2007, s. 458-462.

24 A. Dudek, Heydel Adam, [w:] Stownik historii doktryn politycznych, t. 2, red. M. Jaskólski, Warszawa 1999, s. 395-397.

25 Zweig Ferdynand, [w:] Leksykon myślicieli politycznych i prawnych, red. E. Kundera, M. Maciejewski, Warszawa 2006, s. 494-495. 
Poszukując bezpośrednich inspiracji ideowych redakcji „Najwyższego Czasu!”, sięgnąć należy do cytowanych przez ten tygodnik tekstów, przeważnie obcych autorów. Drukowane były nie tylko artykuły, ale nawet całe książki, niektóre z nich wcześniej wydane przez prowadzoną przez Korwin-Mikkego podziemną Officynę Liberałów. Należały do nich takie tytuły, jak: Psychologia rewolucyi francuskiej konserwatywnego pisarza Teodora Jeske-Choińskiego, Przyptywy i odptywy demokracji przedwojennego urzędnika Ministerstwa Spraw Zagranicznych Aleksandra Trzaski-Chrząszczewskiego ${ }^{26}$, esej Teoria narodowości angielskiego historyka i myśliciela politycznego Lorda Actona, Nowe średniowiecze rosyjskiego filozofa chrześcijańskiego Mikołaja Bierdiajewa, Rewolucja konserwatywna w Ameryce francuskiego publicysty i filozofa Guy Sormana, Socjaldemokratyczny park polskiego dziennikarza występującego pod pseudonimem Stan Spielberg, Wtaściwy porządek rzeczy amerykańskiego dziennikarza konserwatywnego Rusha Limbaugha oraz Bogactwo i ubóstwo amerykańskiego pisarza ekonomiczno-politycznego George’a Gildera ${ }^{27}$. Oprócz kompletnych dzieł drukowano także większe lub mniejsze fragmenty tekstów takich autorów, jak: Frédéric Bastiat, Isaiah Berlin, Milton Friedman, Friedrich August von Hayek, Michael Novak, Karl Popper, Ayn Rand i innych, dodać należy także kilkanaście artykułów przedrukowanych z amerykańskiego pisma libertariańskiego „The Freeman”.

Taki zestaw autorów i tytułów pokazuje w sposób zdecydowany, jakie treści interesują publicystów środowiska skupionego wokół „Najwyższego Czasu!”. Konserwatyzm, liberalizm, libertarianizm, antysocjalizm, antyetatyzm, indywidualizm, wolność, wszystko to podbudowane wartościami i tradycjami wypływającymi z chrześcijaństwa - wśród takiego zbioru idei obracają się wspomniani publicyści. Podążając tymi tropami, autor niniejszego artykułu, mając na uwadze ograniczenia objętościowe czasopisma, zdecydował się zaprezentować tylko kilku, zdaniem autora, najwyrazistszych inspiratorów środowiska tygodnika „Najwyższy Czas!”, takich jak: Adam Smith, Edmund Burke, Frédérick Bastiat, Friedrich August von Hayek i Ludwig von Mises, jako przedstawicieli austriackiej szkoły w ekonomii, oraz Margaret Thatcher

$26 \mathrm{Na}$ tę pozycję zwrócił uwagę Cezary Zawalski, pisząc o inspiracjach historiograficznych Janusza Korwin-Mikkego. Bez wątpienia trzeba zgodzić się z taką opinią, na której potwierdzenie przytoczyć można dość poetycki fragment wypowiedzi prezesa UPR: Sądze, że choć historia nie jest zdeterminowana (tym różnię się od marksistów), to jednak dla żeglującego po wzburzonych wodach przydatne sa wiadomości o prądach, jakie przed rokiem dominowaty w tej cieśninie. Oczywiście, prąd mógt się zmienić - ale praktyka żeglarska uczy, że duże zmiany są nader rzadkie - i mapy morskie sá źródtem użytecznych wskazówek. Oprócz tego, autor tych słów połączył koncepcję cykliczności w historii ze swoją specjalizacją naukową, czyli socjocybernetyką, łącząc ową koncepcję z pojmowaniem społeczeństwa jako homeostatu, dążącego do nieosiągalnego stanu równowagi. Podobne przekonanie o cykliczności rozwoju społeczno-gospodarczego, szczególnie pomiędzy cyklami etatystycznymi (socjalistycznymi) i liberalnymi, wyraża Witold Kwaśnicki. J. Korwin-Mikke, Przedmowa, „Najwyższy Czas!” 1993, nr 34, s. 5-7, 10. Por. C. Zawalski, Prezes..., s. 40; A. Trzaska-Chrząszczewski, Przyptywy i odptywy demokracji, Warszawa 1939; W. Kwaśnicki, Historia myśli liberalnej..., s. 8.

27 To kolejna szczególnie ważna pozycja drukowana na łamach „Najwyższego Czasu!”, a to ze względu na autora, który określany był jako najczęściej cytowany w przemówieniach Ronalda Reagana żyjący autor, a sama książka mianowana została „biblią” lub „katechizmem ekonomicznym” administracji 40. prezydenta Stanów Zjednoczonych. Zob. szerzej: G. Gilder, Bogactwo i ubóstwo, przeł. J. Kropiwnicki, Poznań 2001, Światowy Bestseller. 
i Ronalda Reagana, jako tych, którzy podjęli się próby urzeczywistnienia teorii liberalno-konserwatywnej.

Obecność ojca ekonomii i klasycznego liberalizmu na liście źródeł koncepcji konserwatywnych liberałów nie może budzić wątpliwości. Tak jak u Adama Smitha, w publicystyce „Najwyższego Czasu!” warunkami osiągnięcia osobistego sukcesu są: szeroki zakres indywidualnej wolności, chroniący ją, skuteczny, niezależny wymiar sprawiedliwości, rozbijająca monopole silna konkurencja oraz ograniczona władza państwowa. Te czynniki warunkują rozwój zamożności społeczeństwa ${ }^{28}$. Na łamach tygodnika odbywa się szeroka debata na temat pewnych generaliów konstytuujących ideologię liberalną, w których zakres wchodzą również te wyżej wymienione. Jeden z autorów pisze, że degeneracja liberalizmu nastąpiła w momencie, gdy częściowo oderwał się on od wartości moralnych wyznaczonych przez purytanizm, prezbiterianizm i - szerzej - przez chrześcijaństwo. Tylko część liberałów, która pozostała przy tych wartościach, zasługuje na to miano. Choć w dzisiejszych czasach nazywa się ich raczej konserwatystami, to w rzeczywistości są konserwatywnymi liberałami. Ci, którzy podążyli drogą syntezy z socjalizmem i socjaldemokracją, zatracili swoje korzenie. Jeżeli ktoś odwołuje się do dziedzictwa Smitha, musi patrzeć na gospodarkę i społeczeństwo przez pryzmat moralności, musi uznawać jej tradycyjne, osadzone w religii zasady. Inaczej nie ma prawa nazywać się liberałem ${ }^{29}$. Jest więc szkocki ekonomista wyznacznikiem tego, co można nazywać liberalnym.

Nie wszyscy jednakże podzielają takie uogólnienia. Szczególnie tyczy się to zakresu działania wolnego rynku czy też „niewidzialnej ręki”, jak chciał sam Smith. Według Bartyzela za prawdziwego inspiratora racjonalistycznego leseferyzmu należy uznać Davida Ricarda, przekonanego o istnieniu wielkiego "Zegara Wszechrzeczy”, do którego cztowiek musi się dostroic ${ }^{30}$. Inny argument podaje w swoim artykule Mateusz Machaj, pisząc, że sława Smitha czy Ricarda wcale nie wynika z ich rzeczywistego wkładu w rozwój liberalnej ekonomii i rozpowszechnienie leseferyzmu, lecz z imperializmu naukowego Wielkiej Brytanii. Według niego prawdziwymi twórcami tych idei byli francuscy fizjokraci, tacy jak: Jean Baptiste Say, Ėtienne de Condillac, Richard Cantillon i inni ${ }^{31}$. Istotnie, hasło laissez faire pochodzi od francuskich fizjokratów, ale na Smitha szczególny wpływ wywarł François Quesnay, przez Machaja niewymieniany. Co ważne, system leseferyzmu w założeniu fizjokratów dotyczył sfery gospodarczej, głównie rolnictwa, które uznawane było za jedyną działalność przynoszącą nadwyżki ${ }^{32}$. Smith i jego następcy rozciągnęli go na sferę społeczną i politycznąa ${ }^{33}$.

Istotnym zarzutem, jaki wobec szkockiego ekonomisty mogą mieć publicyści „Najwyższego Czasu!”, jest ograniczenie działania zasady wolnego rynku w oświacie.

28 L. Balcerowicz, Przedmowa, [w:] J. Buchan, Adam Smith. Życie i idee, przeł. K. Rastawicki, Warszawa 2008, s. 8-9.

29 P. Skórzyński, Liberalizm: sztandar czy enigma, „Najwyższy Czas!” 1997, nr 13, s. 4-9.

30 J. Bartyzel, W gaszczu liberalizmów..., s. 110.

31 M. Machaj, Ricardo i jego btędy, „Najwyższy Czas!” 2004, nr 14, s. 38-39.

32 J. Buchan, Adam Smith..., s. 87.

33 W. Bernacki, Leseferyzm, [w:] Stownik historii doktryn politycznych, t. 3, s. 561. 
Smith uważał, że oświata powinna być obowiązkowa i publiczna, aby nie produkować ludzi podatnych na manipulację, partyjniactwo, bunt i fanatyzm ${ }^{34}$. Co ciekawe, w konserwatywno-liberalnym tygodniku znajdziemy argumenty dokładnie odwrotne - że to właśnie publiczna oświata odpowiedzialna jest za zbałamucenie młodych ludzi, za ich podatność na populizm i manipulację umysłami ${ }^{35}$. Wydaje się to efektem różnicy epok. Od czasów Smitha wiele się w oświacie zmieniło, przede wszystkim zwiększyła się jej zależność od państwa. Wciąż jednak, pomimo wielu obwarowań czy ograniczeń programowych, to od nauczyciela zależy, co i w jaki sposób trafi do umysłu ucznia.

Podobnie jak Smith, również Burke jest myślicielem, który w sposób naturalny wpisuje się w koncepcje polskich konserwatywnych liberałów. I nie chodzi tu tylko o jego konserwatywne zapatrywania, ale być może o wiele ważniejsze w tym kontekście poglądy gospodarcze ${ }^{36}$. Panuje powszechne przekonanie, że Burke, tworząc swoje koncepcje ekonomiczne, korzystał z prac Smitha. Jednakże są i tacy, którzy doszukują się tutaj relacji odwrotnej ${ }^{37}$. Niezwykle ważna w tym kontekście jest praca Burke’a Refleksje $i$ dane o nieurodzaju, w której daje on wykład o gospodarce wolnej od wpływu państwa, o państwie ze ściśle określonym zestawem kompetencji i o prawach ekonomii jako prawach naturalnych, wywodzących się z woli Boga ${ }^{38}$. Niemniej jednak w publicystyce „Najwyższego Czasu!" widać wyraźnie wpływy brytyjskiego pisarza.

Za generalną ocenę całości dokonań ideowych Burke’a niech posłuży poniższy cytat: Wielkość Burkéa przejawia się nie tylko w tym, że umiat przewidzieć bieg wypadków historii. Znacznie wazniejsze dziś jest to, że byt on konsekwentnym obronca tych wartości, do których dzisiaj - po latach socjalistycznego zniewolenia - wracamy. To do niego odwota się Hayek, piszac swoją Drogę do niewolnictwa, walcząc z ograniczeniami państwa opiekuńczego. To on będzie pierwszym konserwatystą, świadomym swojej postawy ideowej, a zarazem przekaże następnym pokoleniom wierność tradycji liberalnej, z wolna ustępujacej w ciagu ostatnich 200 lat pod naciskiem autorytaryzmu $i$ totalitaryzmu. Wreszcie jako jeden z niewielu umiat przewidzieć, iż niekontrolowana demokracja może

34 J. Buchan, Adam Smith..., s. 114.

35 A. Pawłowski, Musisz iść do szkoty, „Najwyższy Czas!” 1990, nr 8, s. 6. Zob. także E. Truchel, Przejściowa forma prywatyzacji oświaty, „Najwyższy Czas!” 1990, nr 10, s. 1, 3.

36 Umiejscowienie Burke’a na styku konserwatyzmu i klasycznego liberalizmu staje się powoli oczywistością dla wielu badaczy. Jeśli weźmie się pod uwagę jego związki z Adamem Smithem oraz fakt, iż z dorobku Brytyjczyka korzystali później i zwolennicy konserwatyzmu, i stronnicy liberalizmu, stanie się jasnym, że Burke był konserwatystą liberalnym, choć wiele z elementów liberalizmu krytykował. B. Szlachta, Burke Edmund, [w:] Stownik historii doktryn politycznych, t. 1, red. M. Jaskólski, Warszawa 1997, s. 298-303; por. R. Rydz, Edmund Burke na ścieżkach wolności, Poznań 2005, s. 161-162, Poznańskie Studia Historyczne.

37 R. Rydz, Edmund Burke..., s. 187-188.

38 E. Burke, Refleksje i dane o nieurodzaju, [w:] tenże, O duchu i naturze rewolucji. Wybór pism, wstęp R. Olszowski, B. Szlachta, przeł. A. Wincewicz-Price, Kraków 2012, s. 235-271, Biblioteka Myśli Politycznej, 86. Tekst oryginalny: E. Burke, Thoughts and Details on Scarcity, [w:] Selected Works of Edmund Burke, t. 4: Miscellaneous Writings, Indianapolis 1999, [online] http://oll.libertyfund.org/ ?option $=$ com_staticxt\&staticfile $=$ show.php\%3Ftitle $=659 \&$ chapter $=20399 \&$ \&layout $=$ html\&Itemid=27, 11 II 2014. 
przerodzić się w tyranię większości nad mniejszością, której prawa powinny być należycie zabezpieczone $e^{39}$.

Wśród tych wartości liberalnych szczególną pozycję i zainteresowanie zdobyła sobie u Burke’a własność. Jest ona podstawą egzystencji oraz rozwoju społeczeństwa i państwa. Jednakże bardziej niż jej akumulacja interesowała go ciągłość własności, która gwarantowała egzystencję rodzinie, podstawowej komórce społecznej. Opowiadał się za wolnym rynkiem, we wspominanym już dziele pisat: Bilans konsumpcji i produkcji tworzy cenę. Rynek to spotkanie i narada konsumenta i producenta, które maja miejsce, gdy obie strony odkryja wzajemne potrzeby ${ }^{40}$. Kapitalizm był dla niego naturalnym ładem wyrosłym w czasie ewolucyjnego rozwoju społeczeństwa, stwierdzał on nawet, że dotychczasowy lad hierarchiczny potrzebuje kapitalizmu do dalszego trwania i rozwoju ${ }^{41}$.

W publicystyce analizowanego środowiska widać wyraźnie zasadnicze znaczenie nadawane własności, która winna być podstawowym prawem człowieka, gwarantowanym przez najważniejsze akty prawne w państwie. Niekorzystna jest sytuacja, gdy konstytucja przewiduje możliwość odebrania własności, nawet gdy chodzi tylko o nadzwyczajne sytuacje. $Z$ takiego rozstrzygnięcia wynikać ma zasada, iż własność jest tylko rodzajem nadania państwowego, które może zostać ograniczone, gdy państwo uzna to za konieczne. Zasada bezwzględnej własności prowadzi także do uduchowienia rzeczy, przedmiotów własności. Bezwzględny właściciel w dużo większym stopniu dba o nią, twórczo ją rozwijając, wkładając w nią cząstkę siebie. Ma ona wtedy wymiar intymny, wywołując w posiadaczu wyższe instynkty szacunku i wspomnianej już dbałości, a nie tylko stricte materialny, gdy oznacza po prostu pewną wartość, wyrażoną konkretną sumą pieniędzy ${ }^{42}$.

W jeszcze jednym miejscu poglądy Brytyjczyka urodzonego w Dublinie zbiegają się z publicystyką współczesnych konserwatywnych liberałów, bo trudno uznać jego krytycyzm wobec demokracji za jedyną podstawę tego typu oglądu świata. Burke obawiał się demokracji. Bał się zaniku odpowiedzialności za decyzje, argumentując to tym, że nie można ukarać większości społeczeństwa podejmującej niemądre decyzje. W równym stopniu obawiał się jednak również dyktatury, szczególnie wojskowej, która miałaby kwestionować autorytet władzy, nawet $\mathrm{w}$ armii ${ }^{43}$. Ten drugi wymiar potwierdza powyższe twierdzenie o jedynie zbieżności, a nie podstawie poglądów. Jeśli idzie o sposób podejmowania decyzji politycznych w państwie, to Burke uważał, że powinny one być podejmowane przez specjalnie do tego przygotowanych ludzi, którzy mają lepiej

39 A. Gubrynowicz, Edmund Burke - ciagte wyzwanie, „Najwyższy Czas!” 1999, nr 17, s. 24-25. Zwrócono również uwagę na tekst Burke’a z jego młodości, który jest kłopotliwy z punktu widzenia konserwatystów, gdyż zawiera treści anarchistyczne, a przynajmniej antypaństwowe. M.N. Rothbard, Edmund Burke, anarchista, „Najwyższy Czas!” 2004, nr 18-19, s. 44-46, jest to przedruk artykułu amerykańskiego libertarianina: A Note on Burke's "Vindication of Natural Society”, ,Journal of the History of Ideas" 1958, Vol. 19, nr 1.

E. Burke, Refleksje i dane..., s. 252

$41 \quad$ R. Skarzyński, Konserwatyzm - zarys dziejów..., s. 106.

42 P. Bartula, Wtasność jest wartością, „Najwyższy Czas!” 1990, nr 15, s. 1, 3.

43 B. Szlachta, Konserwatyzm. $Z$ dziejów..., s. 40. 
zdawać sobie sprawę z tego, co jest prawdziwym interesem wspólnoty. Do ludzi takich zaliczał między innymi bogatych handlarzy, posiadaczy ziemskich i w ogóle osoby dysponujące własnością nieruchomą ${ }^{44}$.

Łamy tygodnika pełne są krytycznych ocen demokracji. Tyczą się one szczególnie jej współczesnej formy, będącej, według tych publicystów, zdegenerowanym systemem, który stworzył kastę biurokratów oderwanych od społeczeństwa, dbających przede wszystkim o dobro swoje i swoich bliskich, a sprawy państwa traktujących jako przykry obowiązek. Akt głosowania obywateli jest w takim razie niewypełnioną żadną treścią czynnością, wykonywaną najczęściej nieświadomie przez zmanipulowanych ludzi ${ }^{45}$. Podobnie jak u Burke’a, również tutaj problemem jest egzekwowanie odpowiedzialności za podejmowane decyzje. Demokracja pozwala rozmyć odpowiedzialność za własne działania, a to pozwala na niejasne manipulacje opinią publiczną i wyborcami. Wszystko to w celu utrzymania władzy, a przede wszystkim rządu dusz, co w konsekwencji pozwala „wychować" całe społeczeństwa na lewicową modłę ${ }^{46}$. Poza tym demokracja ma przeszkadzać w przeprowadzeniu skutecznych i kompletnych reform gospodarczych, bo te można przeprowadzać tylko w warunkach niedemokratycznych, kiedy nie jest się związanym przyszłymi wyborami czy umowami koalicyjnymi. Publicysta za przykład podaje gen. Augusta Pinocheta i jego sposób postępowania w Chile ${ }^{47}$.

Przedstawicielem leseferyzmu uznanym przez publicystę „Najwyższego Czasu!” za jednego z ojców austriackiej szkoły w ekonomii jest Frédérick Bastiat. Musi on jednocześnie stać u źródeł myśli eksponowanych w tygodniku. Uznany w publicystyce za wielkiego, choć zapomnianego pisarza krytykującego wszelki interwencjonizm państwowy, propagującego państwo minimum i przede wszystkim sięgającego w swoich analizach poza jednostkowe i chwilowe efekty decyzji gospodarczych. Odwołując się do naukowości ekonomii, Bastiat twierdził, że nie da się sterować gospodarką tylko dlatego, że politycy tak chcą. W ten sposób widać tylko niewielkie efekty takich decyzji, a demagodzy, jak nazywa polityków interwencjonistycznych Bastiat, nie widzą tego, co jest warunkowane prawami ekonomii i pojawi się dopiero po jakimś czasie. Według niego znacznie lepiej jest ponieść na początku pewne straty, by po dłuższym czasie doprowadzić do bogactwa, niż działać odwrotnie, czyli osiągnąć sukces krótkotrwały, kosztem późniejszych kłopotów, a nawet katastrofy ${ }^{48}$. Podobnie myślą publicyści tygodnika, często nawiązując do sposobu rozumowania Francuza. Pokazują, że nie liczy się tylko „tu i teraz”, że decyzje polityczne w gospodarce mają swoje konsekwencje w dużo odleglejszych perspektywach czasowych. Stąd prawdopodobnie wywodzi się

44 R. Skarzyński, Konserwatyzm - zarys dziejów..., s. 95-96.

45 S. Michalkiewicz, Tyrania wspótuczestnictwa, „Najwyższy Czas!” 1996, nr 18-19, s. 27. Zob. również tenże, Polak jako matematyk, „Najwyższy Czas!” 1996, nr 2, s. 1; por. J. Matusiewicz, Demokrata (nadal) nie jestem, „Najwyższy Czas!” 1995, nr 37, s. 14; J. Bartyzel, Wolatbym być chtopcem stajennym..., „Najwyższy Czas!” 1994, nr 1, s. 12.

46 J. Matusiewicz, Demokrata...

47 A. Górski, Warunek naprawy, „Najwyższy Czas!” 1992, nr 2, s. 3.

48 Zob. szerzej: F. Bastiat, Co widać i czego nie widać, przedm. J. Winiecki, przeł. P. Stachura, Lublin 2003. 
również ich nawoływanie do stabilizowania prawa w czasie, poprzez ustanowienie długiego okresu vacatio legis, szczególnie dla ustaw podatkowych ${ }^{49}$.

Drugi z filarów, na których opiera się myśl konserwatywnych liberałów, a który w dużej części pochodzi od Bastiata, jest zakres działania państwa. Francuski pisarz jest w tym względzie uważany także za jednego z ojców libertarianizmu ${ }^{50}$, w stosunku do którego z kolei można znaleźć wiele sympatii na łamach „Najwyższego Czasu!”. Zdaniem Bastiata właściwy zakres działania rządu nie powinien wykraczać poza wspólne danemu społeczeństwu usługi, przez które rozumiał prowadzenie polityki zagranicznej, budowę infrastruktury transportowej czy funkcjonowanie policji. Ta ostatnia jednak nie mogłaby nakazywać jednostkom wykonania prawa, a jedynie reagować w razie łamania sprawiedliwości, czyli wypadków, kiedy jedni ludzie chcą żyć na koszt innych. Najlepszą gwarancją zapewnienia takiego obszaru działania rządu miałaby być całkowita separacja władzy ustawodawczej od władzy wykonawczej. Podobne projekty rozwiązań konstytucyjnych promowane były przez środowisko konserwatywno-liberalne. Personalny i funkcjonalny rozdział władz legł u podstaw projektu konstytucyjnego zaprezentowanego na łamach pisma ${ }^{51}$, a także ustrojowych rozwiązań zaprezentowanych przez drugiego z liderów środowiska, Janusza Korwin-Mikkego ${ }^{52}$.

Kolejnym źródłem inspiracji, które wywarło chyba największy wpływ na ekonomiczne, przede wszystkim, poglądy środowiska konserwatywnych liberałów, była założona przez Carla Mengera wiedeńska szkoła ekonomiczna. Szczególne znaczenie przypisuje się dwóm jej przedstawicielom: Ludwigowi von Misesowi i Friedrichowi Augustowi von Hayekowi. Początkowo ich nauki dotyczące sprzeciwu wobec socjalizmu, interwencjonizmu państwowego czy etatyzmu były przyjmowane na łamach „Najwyższego Czasu!" w sposób niemal dogmatyczny. Już w bardzo ważnym, można powiedzieć programowym, artykule Janusza Korwin-Mikkego w pierwszym numerze pisma zdefiniowane zostało podejście do dychotomii lewica-prawica, co odpowiada przeciwstawieniu socjalizmu i kapitalizmu. Podążając za myślą Misesa, wyrażoną w jego Biurokracjii , że właściwie nie istnieje coś takiego jak „trzecia droga” w zarządzaniu gospodarką, że wszystko, co odbiega od modelu kapitalistycznego, w swoim ostatecznym efekcie będzie socjalizmem, założyciel tygodnika wymienia konkretne dziedziny działalności człowieka świadczące o zsocjalizowaniu (lewicowym charakterze) państwa. Wśród tych dziedzin znajdują się: dotowanie nauki, pomoc dla przemysłu (w jakiejkolwiek postaci), zasiłki

49 J.M. Fijor, Wielki Bastiat, „Najwyżzzy Czas!” 2001, nr 45, s. 36-37. Zob. także S. Michalkiewicz, Projekt nowej konstytucji, „Najwyższy Czas!” 1992, nr 33, s. 3. Por. też inne teksty dotyczące francuskiego ekonomisty: M. Machaj, Pan minister okiem Bastiata, „Najwyższy Czas!” 2002, nr 21, s. 8-9; N. Dueholm, Bastiat pilnie poszukiwany, „Najwyższy Czas!” 2002, nr 32-33, s. 54-55; J. Korwin-Mikke, Bastiat na nowo odkrywany, „Najwyższy Czas!” 2009, nr 39, s. 45.

50 M. Modrzejewska, Libertariańskie koncepcje..., s. 47.

51 Projekt autorstwa Stanisława Michalkiewicza został zaprezentowany w „Najwyższym Czasie!” w numerach 31-34 z roku 1992.

52 Zob. szerzej J. Korwin-Mikke, Wizja parlamentu w nowej konstytucji Rzeczypospolitej Polskiej, Warszawa 1994.

53 L. von Mises, Biurokracja, przeł. J. Kłos, Lublin 2005, s. 22. 
dla bezrobotnych, płaca minimalna, ubezpieczenia zdrowotne, fundusz alimentacyjny, zezwolenie na rozwody, równouprawnienie kobiet w rodzinie, emerytury, aborcja ${ }^{54}$.

Z czasem jednak niektórzy publicyści zaczęli zarzucać Hayekowi odstępstwa od skrajnych reguł kapitalizmu i początkowe fascynacje socjalizmem. Wybuchła dyskusja, w której dwóch głównych adwersarzy umieszczało austriackiego uczonego w dwóch skrajnie różnych tradycjach. Z jednej strony poglądy Hayeka są postrzegane jako libertariańskie, czy może raczej wolnościowe. Publicysta tygodnika opiera takie twierdzenie na sprzeciwie Hayeka wobec konserwatyzmu, przede wszystkimi mając za podstawę jego esej Dlaczego nie jestem konserwatystą? Przyznaje jednocześnie, że wiele koncepcji austriackiego filozofa może kłócić się z wolnościowym postrzeganiem świata, jednak wszystko to ma ostatecznie służyć zachowaniu i zagwarantowaniu wolności tejże jednostki. Trzeba jednak pamiętać, że wiele poglądów Hayeka ma istotnie wymiar wolnościowy, samo już propagowanie wolnego rynku w jak najszerszym wymiarze, mówienie o państwie minimum ma charakter wolnościowy, dla niektórych libertariański. Nie trzeba „na siłę” udowadniać, że krytyczne postrzeganie demokracji i proponowanie w jej miejsce demarchii ma wymiar wolnościowy. Choć można się dopatrzyć takich celów, to nie są one pierwszorzędne. W odpowiedzi na libertariański entuzjazm Tomasza Teluka otrzymujemy całkowitą negację wolnościowego postrzegania Hayeka. Mateusz Machaj stara się udowodnić, że Hayek nie miał nic z libertarianina, nie lubił zasady laissez faire i akceptował etatyzm. Z tego względu nie może być uznany za filozofa dającego podstawy koncepcji prezentowanych na łamach „Najwyższego Czasu!”. Poglądy Machaja są bez wątpienia wsparte autorytetem Hansa Hermanna Hoppego, który w zdecydowany sposób przypisuje Hayekowi socjalistyczne przechylenie.

W związku z tak postawioną sprawą jako jedynego "prawowitego" inspiratora środowiska podaje się Ludwiga von Misesa, który przedkładany jest nie tylko przed Hayeka, ale także innego laureata Nagrody Nobla - Miltona Friedmana. Obu przypisuje się socjaldemokratyczne i etatystyczne efekty ich teorii. Pojawia się nawet insynuacja, poparta argumentacją wspomnianego już Hoppego, że Hayek otrzymał Nobla celowo tak późno i już po śmierci swojego mistrza ${ }^{55}$.

Odnosząc się do tak sformułowanych poglądów, należy zauważyć, że publicysta tygodnika wyrywa z całości poglądów Hayeka jego początkowe „przechylenie socjalistyczne”. Biorąc pod uwagę główne dzieła Austriaka, dochodzi się jednak do odmiennych wniosków. Sądził on bowiem, że cywilizacja rozwijała się w kierunku indywidualizmu i pełnej wolności jednostki. Z czasem jednak państwo zaczęło coraz bardziej ingerować w ten rozwój, przejmując na siebie coraz to większą liczbę problemów, które rzekomo nie mogły być rozwiązane przez jednostkę. W ten sposób doszło do coraz większego i dalej idącego sterowania społeczeństwem ${ }^{56}$.

54 J. Korwin-Mikke, U progu wolności, „Najwyższy Czas!” 1990, nr 1, s. 1, 3, 7.

55 M. Machaj, Mises noblista, „Najwyższy Czas!” 2003, nr 33-34, s. 53-55. Por. T. Teluk, Hayek libertarianin, „Najwyższy Czas!” 2003, nr 44-45, s. 44-45; tenże, Bitwa o Hayeka, „Najwyższy Czas!” 2003, nr 48, s. 34-35; M. Machaj, Jeszcze o Hayeku i innych, „Najwyższy Czas!” 2003, nr 46, s. 28-29.

56 F.A. von Hayek, Droga do zniewolenia, przeł. K. Gurba i in., Kraków 1999, s. 22-35. 
Ten spór o umiejscowienie Hayeka w jednej konkretnej tradycji - konserwatywnej, liberalnej, libertariańskiej - nie jest charakterystyczny jedynie dla publicystów tygodnika. Duża grupa autorów piszących na jego temat nie wypracowała do tej pory jednego stanowiska ${ }^{57}$. Podany powyżej przykład debaty publicystycznej jest tego dowodem, choć oczywiście nie wyczerpuje całości piśmiennictwa konserwatywnych liberałów na temat Hayeka ${ }^{58}$. Sam zainteresowany odżegnuje się od nazywania go i konserwatystą, i liberałem, co uczynił w słynnym eseju Dlaczego nie jestem konserwatysta? ${ }^{59} \mathrm{~W}$ obliczu takiego pomieszania nasuwa się wniosek, że myśl austriackiego ekonomisty i filozofa jest na tyle uniwersalna, że odnajdują się w niej różne kierunki mające u swoich podstaw ulubiony przez samego Hayeka "wigizm”, zawierający - podstawową w tym kontekście - ideę wolności.

Z całego szeregu podobieństw występujących w myśli Hayeka i w koncepcjach publicystycznych opisywanego środowiska należy zwrócić uwagę, oprócz wolnorynkowej gospodarki, na pojęcie sprawiedliwości i sceptycyzm wobec demokracji. Dla Hayeka i publicystów tygodnika jedyną akceptowalną formułą sprawiedliwości jest równość wobec prawa. Każde odstępstwo od tej zasady powoduje jawne nierówności, co jest sprzeczne z jakąkolwiek sprawiedliwością. Dodatkowo prawo powinno wynikać z moralnych zasad, na których swój byt opiera dane społeczeństwo. Prawo to powinno być stabilne, jasne i niezmienne. W przeciwnym wypadku będzie zagrożeniem dla jednostkowej wolności, będącej dobrem najwyższym ${ }^{60}$. Powiązany z zamiłowaniem do tradycji sceptycyzm wobec demokracji doprowadził Hayeka do poszukiwania idealnego systemu rządów. Efektem tych poszukiwań była demarchia, ponieważ ład, mimo iż spontaniczny, nie jest anarchiczny, gdyż jest zbudowany na podstawie tradycji, a chroniony miałby być przez arystokrację naturalną, w której skład wchodziliby ludzie w średnim wieku $^{61}$. Widać tutaj wyraźne podobieństwo w zarysowanej przez Korwin-Mikkego propozycji ordynacji wyborczej, w której wyboru posłów na Sejm miałyby dokonywać osoby w wieku powyżej 40 lat, cieszące się dodatkowo odpowiednim zaufaniem społecznym $^{62}$.

57 W tym miejscu należy wymienić te, zdaniem autora, najważniejsze: W. Sadurski, Neoliberalny system wartości politycznych, Warszawa 1980; J. Godłów-Legiędź, Doktryna spoteczno-ekonomiczna Friedricha von Hayeka, Warszawa 1992, Ekonomia XX Wieku; M. Kuniński, Wiedza, etyka i polityka w myśli F.A. von Hayeka, Kraków 1999, Biblioteka Myśli Politycznej, 24; K. Kostro, Hayek kontra socjalizm. Debata socjalistyczna a rozwój teorii spoteczno-ekonomicznych Friedricha Augusta von Hayeka, Warszawa 2001. Lista ta nie jest wyczerpująca, nie uwzględnia bowiem licznych artykułów naukowych czy haseł encyklopedycznych i słownikowych.

58 A. Gubrynowicz, Fryderyk von Hayek - konserwatywny liberat?, „Najwyższy Czas!” 1999, nr 18-19, s. 33-35; Socjaldemokratyczny Hayek, z Janem Hermanem Hoppe rozmawia M. Machaj, „Najwyższy Czas!" 2004, nr 39, s. 36-37.

F.A. von Hayek, Dlaczego nie jestem konserwatystą, [w:] tenże, Konstytucja wolności, przeł. J. Stawiński, Warszawa 2006, s. 377-390.

W. Bartelski, Doktryna spoteczna von Hayeka, „Najwyższy Czas!” 2001, nr 48, s. 34-35. Por. F.A. von Hayek, Konstytucja..., s. 209-212. 
Jeśli zaś idzie o Misesa, nie ma wątpliwości co do jego poglądów antysocjalistycznych. Są one traktowane jako podstawa funkcjonowania państwa minimum, a to z kolei jest podstawową propozycją programową środowiska konserwatywnych liberałów, wokół której obraca się cała reszta argumentacji ${ }^{63}$. Trochę inaczej rzecz się ma z politycznymi poglądami austriackiego ekonomisty. Zauważa się tutaj jego sympatię dla faszyzmu, choć trzeba dodać, że sam Mises jasno twierdził, że faszyzm (i w ogóle wszelki autorytaryzm) jest systemem zniewalającym jednostkę. Jednakże faszyzm miał przyczynić się do uratowania cywilizacji przed jeszcze większym złem komunizmu i anarchizmu. Był więc swego rodzaju „mniejszym złem”, rozwiązaniem koniecznym w danej chwili. Generalnie Mises był zwolennikiem demokracji parlamentarnej, co w pewien sposób jest mu zarzucane. Ponadto wypomina się Austriakowi jego sympatię dla rządu światowego, którego istnienie miałoby zagwarantować, że narody nie będą walczyły o granice, a więc zostanie osiągnięty pokój tak potrzebny w realizacji wolności jednostki ${ }^{64}$.

Politykami, których stawia się często za wzór cnót konserwatywno-liberalnych, byli Margaret Thatcher i Ronald Reagan. Tych dwoje anglosaskich przywódców, których rządy przypadły na lata 80 . XX wieku, bez wątpienia odcisnęło swoje piętno na poglądach polskich konserwatywnych liberałów. Tym bardziej że interesowali się sprawami Polski, że wspierali ruch solidarnościowy, że ich poglądy były antykomunistyczne i, co w tym miejscu bardzo ważne, odwoływali się do wartości konserwatywnych przy stosowaniu reform wolnorynkowych.

Antykomunizm Ronalda Reagana związany był z podstawową dla tego prezydenta wartością - wolnością. To z niej wynikało przekonanie o konieczności ograniczenia udziału państwa w gospodarce, o walce o wolności osobiste, co z kolei przełożyło się na konkretne decyzje - zmniejszenie podatków, walkę z inflacją, poparcie dla wszelkich form przedsiębiorczości. Wolność dla Reagana oznaczała jednak również wzięcie odpowiedzialności za swoje czyny, co powiązane było z zaostrzeniem kar za najcięższe przestępstwa, a także zwiększeniem bezpieczeństwa poprzez wzmocnienie policji. Odpowiadało to minarchistycznym poglądom na państwo, które wielokrotnie przewijały się przez łamy „Najwyższego Czasu!”65.

Publicystyka konserwatywnych liberałów zwracała szczególną uwagę na skuteczność działań 40. prezydenta USA. Jako jeden z jej przykładów podaje się rozprawienie się ze strajkiem kontrolerów lotniczych w 1981 roku $^{66}$. Podobnie rzecz ma się zresztą także z Margaret Thatcher i jej polityką wobec górniczych związków zawodowych ${ }^{67}$. Jeśli idzie o ekonomiczne aspekty rządów Reagana, bardzo pozytywnie oceniana jest

63 P. Sztąberek, Przestrogi klasyka, „Najwyższy Czas!” 2001, nr 31-32, s. 43. Na temat całości poglądów ekonomicznych Misesa zob. E. Butler, Ludwig von Mises - kompendium myśli ekonomicznej, przeł. M. Bąkówna, Warszawa 2010.

64 T. Teluk, Lepszy faszyzm niż anarchia, „Najwyższy Czas!” 2004, nr 41, s. 30-31. Por. J. Lewiński, P. Mastalarz, Chrystus za permisywizmem, „Najwyższy Czas!” 2004, nr 43, s. 34-36.

65 A. Rzegocki, Reagan Ronald Wilson, [w:] Stownik historii doktryn politycznych, t. 5, red. K. Chojnicka, M. Jaskólski, Warszawa 2012, s. 43-47.

66 T. Sommer, Jak to zrobit Ronald Reagan?, „Najwyższy Czas!” 1998, nr 26, s. 6.

67 S. Sękowski, Lekcja Thatcher do odrobienia, „Najwyższy Czas!” 2008, nr 1, s. 16-18. 
walka z inflacją połączona z obniżką podatków, jaką zastosował w pierwszych latach swojej prezydentury. Bez wchodzenia w szczegóły ekonomiczne, publicysta wychwala taką politykę gospodarczą, twierdząc, że prowadzi ona do zwiększenia zakresu wolności człowieka, a w konsekwencji do większego szczęścia. Walka z inflacją jest niezbędnym warunkiem wzrostu gospodarczego. Jego tempo jednakże uzależnia się od zakresu wolności osobistej, jaką cieszą się obywatele danego państwa. To z kolei przekłada się na efektywność zwalczania inflacji. Trzeba jednak pamiętać, że sukces reaganomiki był także efektem radykalnego zwiększenia deficytu finansów publicznych, a gospodarkę napędzały w dużym stopniu zamówienia wojskowe, spowodowane przyspieszeniem wyścigu zbrojen ${ }^{68}$.

Sukces ekonomiczny reaganomiki nie jest taki oczywisty dla Janusza Korwin-Mikkego. Pisze on, że Reaganowi niewiele udało się zrobić w ekonomii - jedyny sukces to spłaszczenie podatków. Sukces prezydenta miał wziąć się z psychologicznie pozytywnego nastawienia ludności po jego wyborze na urząd. Ludzie, wierząc w tego polityka, zaczęli działać na gruncie przedsiębiorczości i w ten sposób „lokomotywa” gospodarki ruszyła. Natomiast nie można ukryć, że Reagan pozostawił potężny deficyt budżetowy. Korwin-Mikke tłumaczy to tym, że nie zastosował (bo z politycznych powodów nie mógł, nie pozwoliłaby na to większość demokratyczna w Kongresie) jednej z cudownych metod byłego prezesa Unii Polityki Realnej. Miał, mianowicie, zrównoważyć budżet bez dodruku pieniądza, poprzez stworzenie presji podatkowej w postaci niewielkiego podatku pogłównego dla wszystkich. Według Korwin-Mikkego taki podatek zmusza do pracy również biednych, ponieważ nie jest zależny od ich dochodów, więc ma się im to opłacać. W ten sposób mieliby nie popaść w zależność od pomocy socjalnej. Problem polega na tym, że jeżeli taka pomoc by istniała, to sam podatek pogłówny trudno uznać za wystarczający bodziec do podjęcia pracy przez ludzi zagrożonych popadnięciem w socjalną zależność. Prawdopodobnie i przed tą operacją, i po niej ludzie ci pozostawaliby w takiej zależności ${ }^{69}$.

Również była premier Zjednoczonego Królestwa Margaret Thatcher cieszy się dużym uznaniem wśród publicystów tygodnika. Uznana jest za najwybitniejszego premiera czasu pokoju w XX wieku, który to premier zaproponował i zrealizował samodzielny program zmiany społecznej. Jej osiągnięcia sprowadza się do walki z państwem opiekuńczym. To uproszczenie jest oczywiście spowodowane formatem gazety, ale publicysta stara się udowodnić, że w tym względzie Thatcher jest wzorem niedoścignionym.

68 J.M. Fijor, Inflacja a... szczęście, „Najwyższy Czas!” 1999, nr 30-31, s. 54-55. Por. A. Rzegocki, Reagan..., s. 46. Na temat reaganomiki zob. więcej: M. Belka, Reaganomika. Sukces czy porażka?, Wrocław 1991; W.A. Niskanen, Reaganomics, Library of Economics and Liberty, [online] http://www.econlib. org/library/Enc1/Reaganomics.html, 15 II 2014.

69 J. Korwin-Mikke, Wyniki reaganomiki, „Najwyższy Czas!” 1992, nr 45, s. 9. Por. T. Sommer, Niedokończona rewolucja, „Najwyższy Czas!” 2004, nr 24, s. 5-6; J.M. Fijor, Za Reagana, „Najwyższy Czas!” 2004, nr 25, s. 16-17; A. Orkowski, Jego wizja, „Najwyższy Czas!” 2005, nr 6, s. 39; Ł. Adamski, Redwood, „Najwyższy Czas!” 2006, nr 38, s. 38-39; P.P. Styrna, Wielki Triumwirat, „Najwyższy Czas!” 2007, nr 2, s. 37; A. Orkowski, Ten, który pokonat Imperium Zta, „Najwyższy Czas!” 2007, nr 24, s. 46-48. Zob. także J. O'Sullivan, Prezydent, papież, premier. Oni zmienili świat, przeł. P. Amsterdamski, Warszawa 2007. 
Jej poglądy i działania w okresie premierostwa są afirmowane bez żadnej krytycznej refleksji ${ }^{70}$. Kenneth Harris zauważa jednak: Konserwatywne rzady lat osiemdziesiatych - rzekomo tak niechętne wszelkim formom komenderowania - powotaty do życia wiele ustaw ograniczających bezprzyktadnie szeroka game obszarów - od posiadania broni, przestrzegania tajemnic i chuligaństwa kibiców pitkarskich przez prawa homoseksualistów, wytyczne dla stacji radiowo-telewizyjnych, aż po kare śmierci. W neoliberalizmie końca XX wieku tkwi nieodtaczny paradoks, gdyż dotyczy niektórych spotecznych i etycznych konsekwencji leseferyzmu ekonomicznego. Paradoks thatcheryzmu polega na kontraście między zwiększona swoboda gospodarcza jednostki a tendencja centralistyczna, która wniknęta $w$ tak wiele dziedzin dziatalności ludzkiej $j^{71}$. Czy to ma być cel propozycji konserwatywnych liberałów w Polsce? Wydaje się, że coś jest na rzeczy. Szczególnie, gdy zwrócimy uwagę na ich wręcz uwielbienie dla poczynań gen. Augusta Pinocheta w Chile ${ }^{72}$. Zgadza się to także z często powtarzanym bon motem Stefana Kisielewskiego: Wziąć za mordę i wprowadzić liberalizm, czyli najpierw należy zaordynować głębokie reformy gospodarcze, porządkujące kwestie własności i wprowadzające mechanizmy wolnorynkowe, a dopiero później zastanowić się nad wprowadzeniem demokracji, rozumianej jako sposób podejmowania decyzji politycznych.

W realizowanej przez Thatcher polityce i jej koncepcjach szczególną atencją cieszy się również jej podejście do Unii Europejskiej i kwestii suwerenności państwa. Na temat prób federalizowania i unifikowania w ramach Wspólnot Europejskich pisała: Chętna i aktywna wspótpraca pomiędzy niezależnymi i suwerennymi państwami jest najlepszym sposobem na to, by zbudować Wspólnotę Europejska. Europa będzie silniejsza właśnie dlatego, że ma Francję jako Francję, Hiszpanię jako Hiszpanię, Wielką Brytanię jako Wielką Brytanię - każde ze swoimi własnymi zwyczajami, tradycjami i tożsamością. Szaleństwem byłoby próbować stworzyć z nich coś na kształt europejskiej osobowości. Sztuczny zlepek różnych narodowości ${ }^{73}$. W ten sposób zaprezentowana wizja wspólnej Europy jest zbieżna z tym, co proponują publicyści „Najwyższego Czasu!”. Przede wszystkim ma to być strefa wolnego handlu, w przypadku której realizuje się wolność jednostki, umożliwia większy wybór poprzez konkurencję pomiędzy np. systemami podatkowymi, a nie unifikuje się system prawny czy próbuje się wprowadzić jednakową tożsamość europejską ${ }^{74}$.

Dodatkowo, w tym kontekście należy jeszcze zauważyć duże zainteresowanie bliską współpracą ze Stanami Zjednoczonymi, również na gruncie gospodarczym. Miałoby

70 A. Orkowski, Iron Lady, „Najwyższy Czas!” 2005, nr 43, s. 36-37. Por. K. Harris, Margaret Thatcher, przeł. J. Chociłowski, Łódź 1992, s. 7.

${ }^{71}$ K. Harris, Margaret Thatcher, s. 242-243.

72 R. Ziemkiewicz, Czas dla Pinocheta?, „Najwyższy Czas!” 1991, nr 45, s. 8. Zob. także A. Zięba, A co w tym kuble?, „Najwyższy Czas!” 1993, nr 42, s. 15.

73 M. Thatcher, Lata na Downing Street. Wspomnienia z okresu petnienia funkcji premiera rzadu Zjednoczonego Królestwa, przeł. A. Kościukiewicz, K. Michalska, Gdańsk 1996, s. 669.

74 R. Sowiński, Eurototalizm za program, „Najwyższy Czas!” 1992, nr 2, s. 4. Zob. także S. Wojtera, Unia europejskich biurokratów, „Najwyższy Czas!” 2000, nr 9, s. 10-11; P. Toboła-Pertkiewicz, David Cameron-morderca thatcheryzmu, „Najwyższy Czas!” 2007, nr 7, s. 26-27. 
to się realizować poprzez przystąpienie do Północnoamerykańskiej Strefy Wolnego Handlu, co według publicystów konserwatywno-liberalnych miała rozważać także Thatcher $^{75}$.

Podsumowując powyższe rozważania, należy zauważyć i podkreślić, że zaprezentowany zestaw inspiracji nie wyczerpuje w pelni tego tematu. Autor ma tego całkowitą świadomość, wiedząc jednocześnie, że całość znajdzie się w rozprawie doktorskiej, która jest $\mathrm{w}$ fazie przygotowań. Wybór dokonany na potrzeby niniejszego artykułu miał ukazać, skąd biorą się liberalne i konserwatywne wątki myślenia środowiska „Najwyższego Czasu!". Pomimo iż dominują one w całej retoryce tygodnika, nie należy zapominać, że na jego spuściznę składają się też wątki nacjonalistyczne, katolickie (czy szerzej chrześcijańskie), monarchistyczne (co jest częścią konserwatyzmu, ale tutaj wyraźnie wyodrębnioną) i wszelkie inne, a kojarzone z prawicą.

$\mathrm{Na}$ koniec należy wspomnieć o jeszcze jednej postaci, której poglądy wywarły wpływ przede wszystkim na sposób formułowania ocen i opinii publicystów tygodnika. Chodzi o włoskiego ekonomistę, socjologa i filozofa politycznego Vilfreda Pareta, nazywanego „mistrzem prawicy”, a jego koncepcje „kanonem prawicowego myślenia”. Nie dziwi więc czerpanie z niego pełnymi garściami przez środowisko „Najwyższego Czasu!”. Jego analizy społeczne i polityczne pozwalają spojrzeć na świat oczami realisty, nazywać rzeczy po imieniu, nie chować się za neutralnością światopoglądową. Oczywiście ostre sądy, jakie miał w swoim zwyczaju wyrażać Pareto, kłócą się z koniecznością zdobywania poklasku wyborczego, ale poszukiwanie prawdy i mówienie o niej, nawet cyniczne, jest o wiele bardziej nęcące dla konserwatywnych liberałów niż poniżanie się przed masami. W połączeniu z koncepcjami cykliczności historycznej wspomnianego wcześniej Trzaski-Chrząszczewskiego Paretowskie krążenie elit jest chyba doskonałym wytłumaczeniem konsekwencji (konserwatyzmu?) polskiego środowiska spod znaku „Najwyższego Czasu!"”6. Spróbować można tutaj pokusić się o hipotezę, że wzmiankowane środowisko oczekuje na swój cykl, na swój moment historyczny, na swoje miejsce wśród elit, aby wreszcie mogło zrealizować swoje koncepcje i pomysły.

\section{BIBLIOGRAFIA}

\section{Teksty źródłowe}

Adamski Ł., Redwood, „Najwyższy Czas!” 2006, nr 38.

Bartelski W., Doktryna spoteczna von Hayeka, „Najwyższy Czas!” 2001, nr 48.

Bartula P., Wtasność jest wartością, „Najwyższy Czas!” 1990, nr 15.

Bartyzel J., Wolatbym byćchtopcem stajennym..., „Najwyższy Czas!” 1994, nr 1.

Bastiat F., Co widać i czego nie widać, przedm. J. Winiecki, przeł. P. Stachura, Lublin 2003.

75 M. Madelski, Powrót „Żelaznej Damy”, „Najwyższy Czas!” 2002, nr 13-14, s. 30. Zob. także T. Sommer, Polska i N.A.F.T.A., „Najwyższy Czas!” 1998, nr 39, s. 4-6; J.M. Małek, NAFTA, CEFTA czy Unia, „Najwyższy Czas!” 1999, nr 34-35, s. 12-13.

76 T. Gabiś, Pareto - mistrz prawicy, „Najwyższy Czas!” 1993, nr 40, s. 1, 10. 
Burke E., Refleksje i dane o nieurodzaju, [w:] tenże, O duchu i naturze rewolucji. Wybór pism, wstęp R. Olszowski, B. Szlachta, przeł. A. Wincewicz-Price, Kraków 2012, Biblioteka Myśli Politycznej, 86.

Burke E., Thoughts and Details on Scarcity, [w:] Selected Works of Edmund Burke, t. 4: Miscellaneous Writings, Indianapolis 1999, [online] http://oll.libertyfund.org/?option=com_staticxt\&staticfile $=$ show.php\%3Ftitle $=659$ \& chapter $=20399$ \&layout $=$ html\&Itemid $=27$.

Burliński J., Flota bez morza, „Najwyższy Czas!” 1992, nr 4.

Dueholm N., Bastiat pilnie poszukiwany, „Najwyższy Czas!” 2002, nr 32-33.

Fijor J.M., Inflacja a... szczęście, „Najwyższy Czas!” 1999, nr 30-31.

Fijor J.M., Wielki Bastiat, „Najwyższy Czas!” 2001, nr 45.

Fijor J.M., Za Reagana, „Najwyższy Czas!” 2004, nr 25.

Gabiś T., Pareto - mistrz prawicy, „Najwyższy Czas!” 1993, nr 40.

Gilder G., Bogactwo i ubóstwo, przeł. J. Kropiwnicki, Poznań 2001, Światowy Bestseller.

Górski A., Trzeba te pojęcia tączyć, „Najwyższy Czas!” 1992, nr 28.

Górski A., Warunek naprawy, „Najwyższy Czas!” 1992, nr 2.

Gubrynowicz A., Edmund Burke - ciagte wyzwanie, „Najwyższy Czas!” 1999, nr 17.

Gubrynowicz A., Fryderyk von Hayek - konserwatywny liberat?, „Najwyższy Czas!” 1999, nr 18-19.

Hayek F.A. von, Droga do zniewolenia, przeł. K. Gurba i in., Kraków 1999.

Hayek F.A. von, Konstytucja wolności, przeł. J. Stawiński, Warszawa 2006.

Korwin-Mikke J., Bastiat na nowo odkrywany, „Najwyższy Czas!” 2009, nr 39.

Korwin-Mikke J., Przedmowa, „Najwyższy Czas!” 1993, nr 34.

Korwin-Mikke J., U progu wolności, „Najwyższy Czas!” 1990, nr 1.

Korwin-Mikke J., Wizja parlamentu w nowej konstytucji Rzeczypospolitej Polskiej, Warszawa 1994.

Korwin-Mikke J., Wyniki reaganomiki, „Najwyższy Czas!” 1992, nr 45.

Kto z nami, kto przeciwko nam, „Najwyższy Czas!” 1990, nr 7.

Lewiński J., Mastalarz P., Chrystus za permisywizmem, „Najwyższy Czas!” 2004, nr 43.

Machaj M., Jeszcze o Hayeku i innych, „Najwyższy Czas!” 2003, nr 46.

Machaj M., Mises noblista, „Najwyższy Czas!” 2003, nr 33-34.

Machaj M., Pan minister okiem Bastiata, „Najwyższy Czas!” 2002, nr 21.

Machaj M., Ricardo i jego btędy, „Najwyższy Czas!” 2004, nr 14.

Madelski M, Powrót „Żelaznej Damy”, „Najwyższy Czas!” 2002, nr 13-14.

Małek J.M., NAFTA, CEFTA czy Unia, „Najwyższy Czas!” 1999, nr 34-35.

Matusiewicz J., Demokratą (nadal) nie jestem, „Najwyższy Czas!” 1995, nr 37.

Michalkiewicz S., Polak jako matematyk, „Najwyższy Czas!” 1996, nr 2.

Michalkiewicz S., Projekt nowej konstytucji, „Najwyższy Czas!” 1992, nr 33.

Michalkiewicz S., Tyrania wspótuczestnictwa, „Najwyższy Czas!” 1996, nr 18-19.

Mises L. von, Biurokracja, przeł. J. Kłos, Lublin 2005.

Orkowski A., Iron Lady, „Najwyższy Czas!” 2005, nr 43.

Orkowski A., Jego wizja, „Najwyższy Czas!” 2005, nr 6.

Orkowski A., Ten, który pokonat Imperium Zta, „Najwyższy Czas!” 2007, nr 24.

Pawłowski A., Musisz išć do szkoty, „Najwyższy Czas!” 1990, nr 8.

Rothbard M.N., Edmund Burke, anarchista, „Najwyższy Czas!” 2004, nr 18-19.

Sękowski S., Lekcja Thatcher do odrobienia, „Najwyższy Czas!” 2008, nr 1. 
Skórzyński P., Liberalizm: sztandar czy enigma, „Najwyższy Czas!” 1997, nr 13.

Socjaldemokratyczny Hayek, z Janem Hermanem Hoppe rozmawia M. Machaj, „Najwyższy Czas!” 2004, nr 39.

Sommer T., Jak to zrobit Ronald Reagan?, „Najwyższy Czas!” 1998, nr 26.

Sommer T., Niedokończona rewolucja, „Najwyższy Czas!” 2004, nr 24.

Sommer T., Polska i N.A.F.T.A., „Najwyższy Czas!” 1998, nr 39.

Sowiński R., Eurototalizm za program, „Najwyższy Czas!” 1992, nr 2.

Styrna P.P., Wielki Triumwirat, „Najwyższy Czas!” 2007, nr 2.

Sztąberek P., Przestrogi klasyka, „Najwyższy Czas!” 2001, nr 31-32.

Teluk T., Bitwa o Hayeka, „Najwyższy Czas!” 2003, nr 48.

Teluk T., Hayek libertarianin, „Najwyższy Czas!” 2003, nr 44-45.

Teluk T., Lepszy faszyzm niż anarchia, „Najwyższy Czas!” 2004, nr 41.

Thatcher M., Lata na Downing Street. Wspomnienia z okresu petnienia funkcji premiera rzadu Zjednoczonego Królestwa, przeł. A. Kościukiewicz, K. Michalska, Gdańsk 1996.

Toboła-Pertkiewicz P., David Cameron - morderca thatcheryzmu, „Najwyższy Czas!” 2007, nr 7.

Truchel E., Przejściowa forma prywatyzacji oświaty, „Najwyższy Czas!” 1990, nr 10.

Trzaska-Chrząszczewski A., Przyptywy i odptywy demokracji, Warszawa 1939.

Wojtera S., Unia europejskich biurokratów, „Najwyższy Czas!” 2000, nr 9.

Ziemkiewicz R., Czas dla Pinocheta?, „Najwyższy Czas!” 1991, nr 45.

Zięba A., A co w tym kuble?, „Najwyższy Czas!” 1993, nr 42.

\section{Literatura}

Balcerowicz L., Przedmowa, [w:] J. Buchan, Adam Smith. Życie i idee, przeł. K. Rastawicki, Warszawa 2008.

Bartyzel J., Konserwatyzm bez kompromisu. Studium z dziejów zachowawczej myśli politycznej w Polsce wXX wieku, Toruń 2001.

Bartyzel J., W gaszczu liberalizmów. Próba periodyzacji i klasyfikacji, Lublin 2004, Biblioteka Cywilizacji.

Belka M., Reaganomika. Sukces czy porażka?, Wrocław 1991.

Bernacki W., Krzyżanowski Adam, [w:] Stownik historii doktryn politycznych, t. 3, red. M. Jaskólski, Warszawa 2007.

Bernacki W., Leseferyzm, [w:] Stownik historii doktryn politycznych, t. 3, red. M. Jaskólski, Warszawa 2007.

Butler E., Ludwig von Mises - kompendium myśli ekonomicznej, przeł. M. Bąkówna, Warszawa 2010.

Dudek A., Heydel Adam, [w:] Stownik historii doktryn politycznych, t. 2, red. M. Jaskólski, Warszawa 1999.

Godłów-Legiędź J., Doktryna spoteczno-ekonomiczna Friedricha von Hayeka, Warszawa 1992, Ekonomia XX Wieku.

Harris K., Margaret Thatcher, przeł. J. Chociłowski, Łódź 1992.

Heywood A., Ideologie polityczne. Wprowadzenie, przeł. M. Habura, N. Orłowska, D. Stasiak, red. nauk. T. Żyro, Warszawa 2007.

Kłos J., Wolność, indywidualizm, postęp. Liberalizm konserwatywny wobec nowoczesności, Lublin 2007. 
Kostro K., Hayek kontra socjalizm. Debata socjalistyczna a rozwój teorii spoteczno-ekonomicznych Friedricha Augusta von Hayeka, Warszawa 2001.

Kuniński M., Wiedza, etyka i polityka w myśli F.A. von Hayeka, Kraków 1999, Biblioteka Myśli Politycznej, 24.

Kwaśnicki W., Historia myśli liberalnej. Wolnossć, wtasność, odpowiedzialność, Warszawa 2000.

Leksykon myślicieli politycznych i prawnych, red. E. Kundera, M. Maciejewski, Warszawa 2006.

Machaj Ł., Za i przeciw Europie. Integracja europejska w polskiej myśli politycznej w latach 1989-2001, Wrocław 2006, Acta Universitatis Wratislaviensis, 2952.

Mich W., Myśl polityczna polskiego ruchu konserwatywnego, Lublin 1994, Wyktady Otwarte $U M C S, 10$.

Modrzejewska M., Libertariańskie koncepcje jednostki i państwa we wspótczesnej amerykańskiej myśli politycznej, Kraków 2010, Prace Amerykanistyczne UJ.

Niskanen W.A., Reaganomics, Library of Economics and Liberty, [online] http://www.econlib. org/library/Enc1/Reaganomics.html.

O’Sullivan J., Prezydent, papież, premier. Oni zmienili świat, przeł. P. Amsterdamski, Warszawa 2007.

Rau Z., Liberalizm. Zarys myśli politycznej XIX i XX wieku, Warszawa 2000, Biblioteka Aletheia, 10.

Rydz R., Edmund Burke na ścieżkach wolności, Poznań 2005, Poznańskie Studia Historyczne.

Rzegocki A., Reagan Ronald Wilson, [w:] Stownik historii doktryn politycznych, t. 5, red. K. Chojnicka, M. Jaskólski, Warszawa 2012.

Sadurski W., Neoliberalny system wartości politycznych, Warszawa 1980.

Skarzyński R., Konserwatyzm - zarys dziejów filozofii politycznej, Warszawa 1998.

Skarzyński R., Od liberalizmu do totalitaryzmu. Z dziejów myśli politycznej XX w., t. 1, Warszawa 1998, Studia i Materiaty Wyższej Szkoty Dziennikarstwa im. Melchiora Wańkowicza $w$ Warszawie, 1.

Sordyl G., Spadkobiercy Stańczyków. Doktryna konserwatyzmu polskiego w latach 1979-1989, Kraków 1999, Ararat.

Szacki J., Liberalizm po komunizmie, Kraków-Warszawa 1994, Demokracja.

Szlachta B., Burke Edmund, [w:] Stownik historii doktryn politycznych, t. 1, red. M. Jaskólski, Warszawa 1997.

Szlachta B., Konserwatyzm. Z dziejów tradycji myślenia o polityce, Kraków-Warszawa 1998.

Szlachta B., Z dziejów polskiego konserwatyzmu, Kraków 2000, Ararat.

Wandowicz K., Wspótczesny konserwatyzm polityczny w Polsce (1989-1998), Wrocław 2000, Acta Universitatis Wratislaviensis. Politologia, 30.

Zawalski C., Prezes. Janusz Korwin-Mikke - publicysta i polityk, Warszawa 2004.

Mgr Grzegorz ĆWIĘKAŁA - asystent w Instytucie Politologii PWSZ im. rtm. Witolda Pileckiego w Oświęcimiu, słuchacz studiów III stopnia w Instytucie Europeistyki UJ. Zainteresowania badawcze: współczesna myśl polityczna Polski i świata, systemy polityczne państw współczesnych, marketing polityczny i public relations, problemy społeczeństwa obywatelskiego. 